\title{
CUELLO: RESOLVING THE CHRONOLOGY THROUGH DIRECT DATING OF CONSERVED AND LOW-COLLAGEN BONE BY AMS ${ }^{1}$
}

\author{
I. A. LAW $W^{2}$, R. A. HOUSLEY $Y^{3}$, NORMAN HAMMOND ${ }^{4}$ and R. E. M. HEDGES
}

\begin{abstract}
It is well known that ${ }^{14} \mathrm{C}$ dating of fossil bone with seriously depleted protein levels, or bone that has been consolidated with preservatives, can produce erroneous results. In the tropics, warm and moist soil conditions lead to constant reworking of organic matter and add to the danger of bone contamination. Because of this, ${ }^{14} \mathrm{C}$ dating of preservative-impregnated bone from such areas has rarely been successful. We report here a set of AMS dates on both unconsolidated animal bone and polyvinyl acetate/polyvinyl alcohol (PVA/PV-OH) impregnated human burials from the Maya site of Cuello, Belize. The steps needed to purify the samples are described, together with details on the use of qualitative infra-red (IR) spectra as a means of assessing sample purity.
\end{abstract}

\section{INTRODUCTION}

The site of Cuello, situated on the eastern margin of the rain-forest zone of the Maya Lowlands in northern Belize $\left(18^{\circ} 05^{\prime} \mathrm{N}, 88^{\circ} 35^{\prime} \mathrm{W}\right)$, is well known for its long sequence of occupation spanning the Formative period (notionally 2000 B.C.-A.D. 250) of Mesoamerican prehistory (Donaghey et al. 1976; Hammond 1980; Pring \& Hammond 1982). A Classic period (A.D. 250-900) occupation also exists, and recently, some evidence for subsequent Postclassic activity has been found (Hammond, Housley \& Law 1991).

The dating of the Preclassic at Cuello has been controversial and widely debated (Hammond et al. 1979; Coe 1980; Marcus 1983, 1984; Hammond 1984; Andrews 1986; Andrews \& Hammond 1990). For most Maya sites, the traditional chronology was based on archaeological evidence, particularly on the ceramic typology. Historical dates were derived from monumental inscriptions placing the Classic period in the first millennium A.D., and dates for the preceding Preclassic (or Formative) period were constructed from best guesses in the pre-radiocarbon era (cf. Smith 1955). Even when radiocarbon dating became available and was applied to the Preclassic, few dates were run. Further, the absence of a discrepant historical chronology muted the impact of tree-ring calibration curves when they were introduced in the 1960s. For most Mesoamerican prehistorians, radiocarbon ages and calibrated dates were equivalent and comparable data, leading to some curious misinterpretations.

The survival of the "guesstimate" chronology for the Maya Preclassic meant that any differing radiocarbon chronology, and/or the use of calibrated dates, which would, in most cases, extend the sequence back in time, would be controversial; this was amply demonstrated in the case of the Preclassic sequence at Cuello.

Following the first excavations at Cuello in 1975-1976, when a previously unknown early ceramic phase (Swasey) was defined stratigraphically below the widely-documented Mamom and Chicanel sphere occupations, radiocarbon dates on wood charcoal from Preclassic contexts of all three ceramic periods were made by the laboratories at the University of California, Los Angeles (UCLA) and Cambridge (Q) (Hammond et al. 1976, 1977). These dates indicated a "long" chronol-

\footnotetext{
${ }^{1}$ Work was carried out in 1989 when Hammond was a Visiting Fellow of Worcester College, Oxford.

${ }^{2}$ Callanish Ltd., Breasclete, Isle of Lewis, UK

${ }^{3}$ Oxford Radiocarbon Accelerator Unit, Research Laboratory for Archaeology and the History of Art, University of Oxford, 6, Keble Road, Oxford OX1 3QJ UK

${ }^{4}$ Department of Archaeology, Boston University, 675 Commonwealth Avenue, Boston, Massachusetts 02215 USA
} 
ogy (Fig. 1) with the Swasey phase from ca. 2500 to ca. 1300 cal. B.C. The Lopez Mamom phase lasted from $1300 \mathrm{cal}$. B.C. to $c a .450$ cal. B.C., and the Cocos Chicanel from $450 \mathrm{cal}$. B.C. to the beginning of the historically defined Classic period in A.D. 250, this last span agreeing with the accepted estimated duration of Chicanel. The two laboratories showed good internal consistency and good agreement (to within one standard deviation), when both stratigraphically adjacent and divided single samples were dated. Hammond et al. (1979) saw no reason to reject the radiocarbon chronology, despite the fact that, on archaeological grounds, it disrupted some preconceived notions about the existence of an occupation in the formally defined Early Preclassic period prior to 1000 B.C. in the Maya Lowlands. Although the close similarity to Middle Preclassic pottery had been noted, as had the distinction from Early Preclassic ceramics from other regions of Mesoamerica, the assignment of the Swasey material to the Early Preclassic was believed necessary on chronological grounds. Some scholars accepted this (e.g., Lowe 1978), whereas others (e.g., Coe 1980: 34-35; Marcus 1984) believed that the ceramic similarities had priority, and that a Middle Preclassic affiliation was in order, despite the radiocarbon dates.

Subsequent dating of charcoal samples from the 1979-1980 excavation seasons by the radiocarbon laboratories at Cambridge (Andrews \& Hammond 1990: Table 1) and La Jolla (Linick 1984) pro-

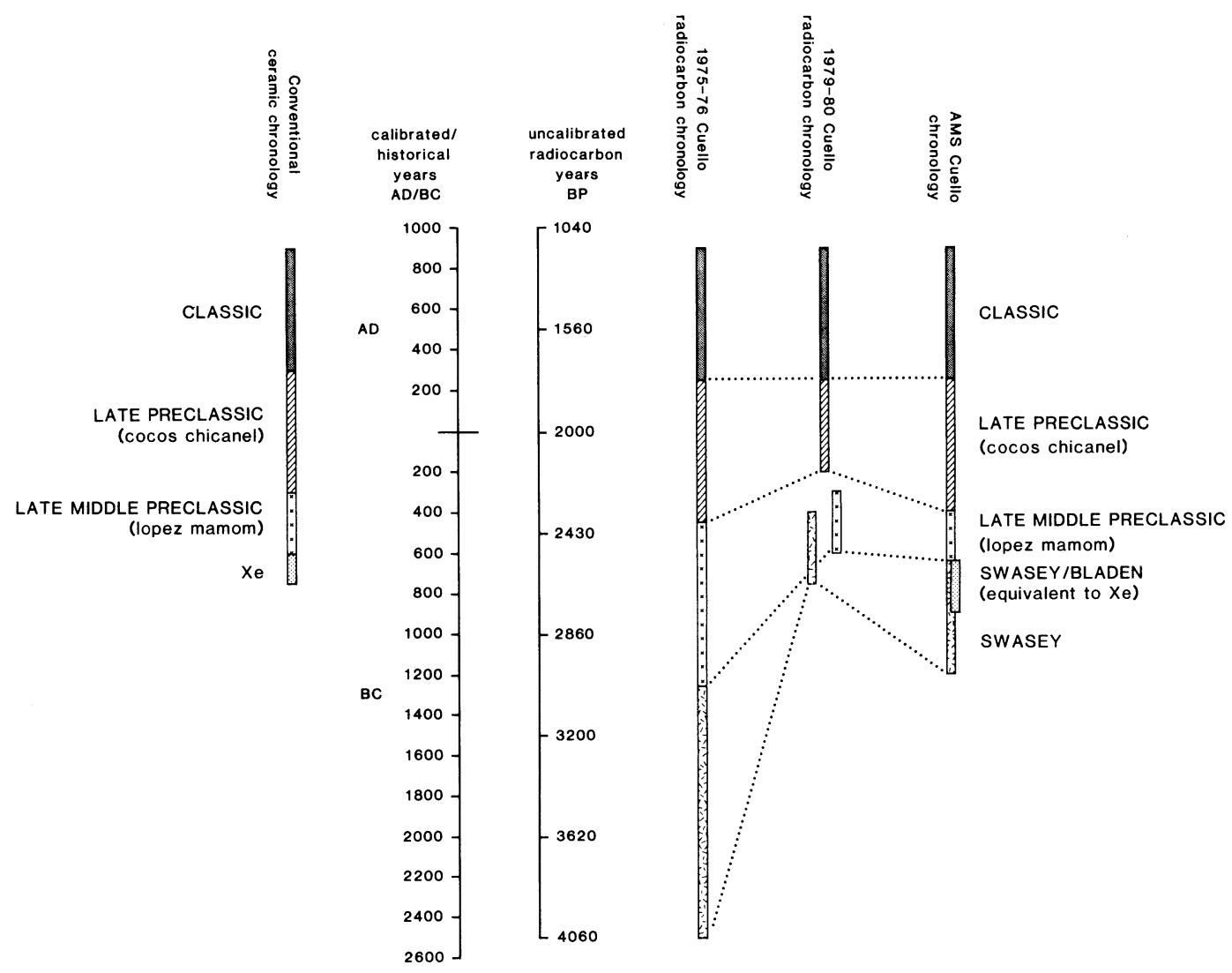

Fig. 1. Conventional (ceramic) chronology for Mesoamerica compared with the "short" and "long" radiometric ${ }^{14} \mathrm{C}$ chronologies of the Cambridge (Q), Los Angeles (UCLA) and La Jolla (LJ) laboratories, and the AMS chronology proposed here. Courtesy of the Research Laboratory for Archaeology and the History of Art, Oxford University. 
duced a second, discrepant chronology (Fig. 1), which indicated a much shorter period of occupation. Again, the laboratories agreed, but no answer could be found as to why the second suite of dates "compressed" the sequence into a shorter time period. The suggestion that anciently burned wood was recycled into later deposits, giving erroneously early dates for Swasey, but also becoming progressively masked by larger quantities of contemporary carbon as the occupation of Cuello developed (Andrews \& Hammond 1990), is not of itself implausible. Yet it does not explain why the 1975-1976 and 1979-1980 excavations of adjoining areas, with visibly continuous stratigraphy, should yield contrasting suites of dates, nor the origin of the ancient burning.

The contrast in chronologies, which demonstrably were neither the result of excavation techniques and personnel (the same from year to year) nor of laboratory procedures (since two laboratories produced similar results in each case) remains a mystery. Yet the dating of Cuello needed to be resolved - the "long" chronology had been cogently challenged, but some of the radiocarbon ages obtained on the "short" chronology were far too late even for the conventional "guesstimate" time scale of the Maya Preclassic.

A fresh approach was indicated, based on dating short-lived material from the relevant occupation layers. Since maize kernels, the most abundant such remains, were also important for paleoethnobotanical studies and could not be sacrificed for dating, although one experimentally dated fragment yielded a satisfactory result (Hammond \& Andrews 1990: Table 1, Sample AA-458), we decided to date human bone from burials. The contemporaneity of the bones with their archaeological context was unquestioned, and the associated grave goods linked the human remains directly to the cultural sequence. Because of the poor condition of the bone after several millennia in a leaching tropical environment, insufficient collagen remained for conventional ${ }^{14} \mathrm{C}$ dating. Thus, AMS dating was employed.

In light of the problems described above, and of cogent arguments that the ceramic chronology proposed by Hammond et al. (1979) was too early (Marcus 1984), we made an attempt, in 1985, to date human bone collagen from Cuello by AMS, in order to resolve the controversy. Two Preclassic human skeletons were sampled (Burial 62, Context [F110] of the Swasey phase, the earliest interment at the site and Burial 5, Context [76/137] of the Bladen phase (now reassigned by Andrews \& Hammond (1990) to early Lopez Mamom)) and dated, using the pretreatment methods outlined in Gillespie, Hedges \& Humm (1986). The dates obtained (OxA-361: $2460 \pm 80$ and OxA-362: $2390 \pm 90$ B.P., respectively; Gowlett et al. 1986: 122) failed to resolve matters: they were statistically identical at one sigma, despite the substantial vertical stratigraphic gap between the burials. Both dates were also later than expected, OxA-361 by over a millennium when compared to the established "long" chronology, OxA-362 by several centuries, although the 800-400 cal. B.C. calibration "plateau" complicated the problem, as did the low level of preserved collagen. On the basis of the dates reported here, Burial 62 (OxA-361) should have yielded a date of $c a .2840$ B.P.; reevaluation of the stratigraphic position of Burial 5 (Andrews \& Hammond 1990) now renders OxA-362 fully acceptable.

We think these initial AMS dates could be in error for the following reasons:

1. Both bones contained only $5 \%$ of their original collagenous protein (using the Gillespie et al. (1986) method - subsequent research showed that only $0.17 \%$ could be extracted and purified as bone amino acids - see Hedges and Law (1989), and references therein, for fuller discussion).

2. Constant reworking of organic matter in tropical climates makes the probability of environmental contamination high. The effect of such contamination increases as the 
collagen content of the bone decreases.

3. Both samples had been consolidated with a PVA/PV-OH emulsion during excavation, although this was not recognized at the time as being important, and thus, was not emphasized to the laboratory.

Once these factors were appreciated, a series of bones from Cuello burials was selected for another dating attempt, and for testing new pretreatment procedures developed specifically to overcome such problems. Infra-red (IR) spectra of final and intermediate fractions from the consolidated bones were recorded to monitor the effect of the various purification steps, and for consideration when assessing the accuracy of the dating results.

\section{PRETREATMENT STRATEGY}

"Control" samples of animal bone from clearly defined Preclassic contexts at Cuello were included in the experiment. These came from Contexts [Q114] and [Q146], occupation deposits of the Lopez Mamom phase (650-400 cal. B.C.), recycled as fill in a construction event at the beginning of the Cocos Chicanel phase (400 cal. B.C.-A.D. 250), the dating of which was approximately the same on the conventional "long" and "short" chronologies (see Fig. 1). The bone had not been consolidated or conserved in any way, and served to check that our pretreatment could overcome the problems associated with high levels of environmental contamination and low levels of collagen. (The level of collagen used here is defined as the weight of total amino acid obtained from hydrolysis of 'gelatin' prepared by the methods outlined below. In our experience, the amino-acid composition of such a preparation is generally collagenous, at least when the collagen level is greater than $5-10 \mathrm{mg} \mathrm{g}^{-1}$ bone).

Two additional human burial samples, from Burials 10 [F7] and 62, were treated as a pilot study aimed at assessing the effectiveness of our laboratory pretreatment on conserved, low-collagen bones. For this reason, three dating fractions were isolated from each bone: 1) total acid-insoluble fraction ("crude collagen"); 2) aqueous, pH3, extract of this ("crude gelatin"); 3) purified gelatin ("ion-exchanged gelatin"). Qualitative IR spectra were used to estimate the purity of the fractions and, hence, the reliability of the radiocarbon ages obtained.

Samples followed from Burials 123 [F251] and 7 [17 F232], which we treated on the basis of the results obtained from Burials 10 and 62, with only one dating fraction (amino acids from purified gelatin) being isolated from each bone. However, we isolated sub-samples of gelatin and ion-exchanged gelatin as intermediates in the process, and recorded qualitative IR spectra.

A purely archaeological inquiry was also added to the experiment. The superficial layers at Cuello included pottery of the Classic period (A.D. 250-900) and some evidence for Postclassic activity. Animal bones, fragments of unidentified large mammal - cervid most likely, from four of these contexts were dated (Q44, Q23, Q74, Q109). Of these, the latter two were from the latest known architectural features, and might thus indicate how long occupation at Cuello had continued. All of the samples were free of consolidant, so IR spectra were not recorded on intermediate fractions.

\section{EXPERIMENTAL DETAILS}

Precleaning. All bones were cleaned mechanically ("shot blasted") before being crushed to a fine powder in a liquid-nitrogen-cooled "Spex" freezer mill.

Extraction of Consolidants. Bones from Contexts [F7] and [F110] were leached sequentially with hot distilled water, methanol $\left(\right.$ at $60^{\circ} \mathrm{C}$ ), and acetone at room temperature. Leachates were evapo- 
rated to dryness, but no extractable components were observed. The bones from Contexts [F251] and [F232] were extracted with acetone under reflux for several hours, but again, there was little evidence that this process removed adsorbed consolidants.

Demineralization and Extraction of "Collagen." The dried bone powders were demineralized using the semi-automated continuous-flow method described in Law and Hedges (1989). Briefly, bone powder is retained within a glass and PTFE flow cell, through which solutions are passed sequentially. In this way, the bone is demineralized with $0.5 \mathrm{M}$ hydrochloric acid to obtain the total acid-insoluble residue. This is leached with $0.1 \mathrm{M}$ sodium hydroxide, and then rinsed thoroughly with distilled water, to produce the "crude collagen" fraction.

Extraction and Purification of Gelatin. Gelatin is extracted from the crude collagen by adjusting the $\mathrm{pH}$ of the water within the cell to 3.0 with dilute hydrochloric acid. The cell is then sealed, and heated at $100^{\circ} \mathrm{C}$ overnight. This process causes collagenous protein to dissolve, leaving the largely water-insoluble polymers, such as polyvinyl acetate (PVA), as a residue, which can be removed by filtration. When dry, the filtrate constitutes the "crude gelatin" fraction. The crude gelatin can be purified further, in some cases, by ion exchange. The gelatin is applied in solution at $\mathrm{pH} 3$ to a column of BioRad AGMP-50 resin, and can be desorbed in $1.5 \mathrm{M} \mathrm{NH}_{4} \mathrm{OH}$ (Law \& Hedges 1989; Hedges \& Law 1989).

Hydrolysis of Purified Gelatin and Ion Exchange of Amino Acids. The dried sample is hydrolyzed in $6 \mathrm{M}$ hydrochloric acid, at $105^{\circ} \mathrm{C}$ overnight, using $1 \mathrm{~mL}$ of acid per $15 \mathrm{mg}$ of protein. When cool, the hydrolyzate can be decolorized, using activated charcoal or BioBeads SM-2 resin, before being filtered and dried under vacuum to remove excess hydrochloric acid. After redissolving in water, the sample is desalted by ion exchange on Dowex 50W-X8 resin (eluted with $\mathrm{NH}_{4} \mathrm{OH}$ ). Pretreatment yields are recorded in Table 1 .

TABLE 1. Pretreatment Results

\begin{tabular}{llcccc}
\hline Burial & Context & $\begin{array}{c}\text { Weight of } \\
\text { bone used }(\mathrm{g})\end{array}$ & $\begin{array}{c}\text { Fraction } \\
\text { isolated* }\end{array}$ & $\begin{array}{c}\text { Yield } \\
\left(\mathrm{mg}^{-1} \mathrm{~g}^{-1}\right)\end{array}$ & $\begin{array}{l}\% \mathrm{wt} \\
\text { yield }\end{array}$ \\
\hline- & {$[\mathrm{Q} 114]$} & 7.5 & 1 & 8.9 & 0.12 \\
- & {$[\mathrm{Q} 146]$} & 7.5 & 1 & 10.0 & 0.13 \\
10 & {$[\mathrm{~F} 7]$} & 2.8 & 2 & 10.7 & 0.38 \\
10 & {$[\mathrm{~F} 7]$} & 2.8 & 3 & 7.1 & 0.25 \\
10 & {$[\mathrm{F7}]$} & 2.8 & 4 & 5.3 & 0.19 \\
62 & {$[\mathrm{~F} 110]$} & 2.6 & 2 & 19.2 & 0.74 \\
62 & {$[\mathrm{~F} 110]$} & 2.7 & 3 & 5.5 & 0.20 \\
62 & {$[\mathrm{~F} 110]$} & 2.1 & 1 & 3.6 & 0.17 \\
123 & {$[\mathrm{~F} 251]$} & 1.7 & 1 & 5.6 & 0.33 \\
7 & {$[17$ F232] } & 1.6 & 1 & 17.25 & 1.08 \\
- & {$[\mathrm{Q} 44]$} & 1.06 & 1 & 95.0 & 8.96 \\
- & {$[\mathrm{Q} 23]$} & 1.45 & 1 & 60.3 & 4.16 \\
- & {$[\mathrm{Q} 74]$} & 1.3 & 1 & 43.0 & 3.31 \\
- & {$[\mathrm{Q} 109]$} & 3.0 & 1 & 0.53 & 0.02 \\
\hline
\end{tabular}

*Key: 1 = amino acids from ion-exchange gelatin

2 = crude collagen

$3=$ crude gelatin

$4=$ ion-exchange gelatin 
Infra-Red Spectroscopy. Qualitative IR spectra of the isolated fractions were obtained by grinding together $1 \mathrm{mg}$ of sample and $20 \mathrm{mg}$ of $\mathrm{KBr}$ with an agate pestle and mortar, pressing this into a disk, and recording the spectrum against a $\mathrm{KBr}$ blank on a Perkin-Elmer 1420 double beam spectrophotometer.

\section{RESULTS AND DISCUSSION}

We dated the samples using the Oxford AMS system, the operation of which has been discussed elsewhere (Hedges et al. 1989). Table 1 records pretreatment yields. Tables 2-3 present data from the IR spectra; Table 4 shows the ${ }^{14} \mathrm{C}$ measurements and the calibrated age ranges.

\section{INFRA-RED SPECTROSCOPY IN DETECTING CONTAMINATION OF PROTEIN BY CONSOLIDANT}

IR spectroscopy is used widely in the identification of synthetic polymers. To a lesser extent, it has been used in the study of protein structures (Timasheff \& Susi 1966). Most synthetic polymers give diagnostic "fingerprint" spectra, and positive identifications can be made when the spectrum of the unknown compound matches that of a known standard material. With extracts from archaeological samples, complex spectra may be obtained, e.g., when mixed polymer emulsions have been used, or when the bone has undergone several conservation treatments with different materials. Some polymer preparations "age," leading to cross-linking reactions (Horie 1987), and altering the spectra obtained. For the present samples, we know that only one type of consolidant has been used Vinamul 6815. This is a PVA/PV-OH emulsion that contains other minor constituents, and which is known to become insoluble with time through cross-linking reactions (J. Spriggs, personal communication 1989). The main IR absorption bands for PVA and polyvinyl alcohol (PV-OH) are shown in Table 2, and the presence of these peaks in the spectra of protein samples can indicate contamination by consolidant.

Collagen and gelatin share a characteristic IR spectrum, shown in Figure 2 and interpreted in Table 2. Diagenesis of protein eventually leads to changes in the IR spectrum, and these can lead to confusion, especially when contamination by a consolidant is also suspected.

The Preclassic Burial Samples. Table 3 illustrates the general trend found during the purification of proteins and peptides extracted from the consolidated human bone samples. It is clear that the "crude collagen" fractions are contaminated with PVA and PV-OH, although protein amide bands are also present. Gelatinization and filtration remove absorbance features associated with the consolidant from all samples except Burial 62; in this sample, the main contaminant is PV-OH. It is difficult to be sure that PVA has been removed, as the acetate $\mathrm{C}=\mathrm{O}$ absorbance may be masked by peptide bands, especially in the samples from Burials 7 and 123. However, the peptide bands at $1725 \mathrm{~cm}^{-1}$ are relatively sharp, and this would not be the case if they were overlapped by the $1740 \mathrm{~cm}^{-1}$ acetate absorbance. It is worth noting that the spectrum for Burial 10 shows this sample to be particularly pure, a slight enhancement of the $1240 \mathrm{~cm}^{-1}$ band being the only sign of contamination.

Confirmation that the $1725 \mathrm{~cm}^{-1}$ peak is due to carboxylic acid groups is found when the gelatin fractions are ion-exchanged, and isolated as the ammonium salts, $-\mathrm{COO}^{-} \mathrm{NH} 4^{+}$. Salt formation causes the - $\mathrm{COOH}$ band to disappear, with the simultaneous appearance of a sharp absorbance peak at $c a .1400 \mathrm{~cm}^{-1}$, due to the $-\mathrm{COO}^{-}$anion, and this is observed with the present samples (Fig. 3B). The similarity between the spectra of the peptized samples (Fig. 3A), with that obtained by the partial hydrolysis of modern collagen (Fig. 2B), proves that the - $\mathrm{COOH}$ groups are due to peptization of the proteins, either caused by diagenesis, or a result of the gelatinization procedure. No other source of $-\mathrm{COOH} /-\mathrm{COO}^{-}$groups, at the levels observed, is possible. The simultaneous 
TABLE 2. Interpretation of major infra-red (IR) absorption bands for polyvinyl acetate (PVA), polyvinyl alcohol (PV-OH), collagen/gelatin, and peptides *

\begin{tabular}{|c|c|}
\hline $\begin{array}{l}\text { Absorbance } \\
\left(\text { Wave number in } \mathrm{cm}^{-1} \text { ) }\right.\end{array}$ & Assignment \\
\hline $\begin{array}{l}\text { PVA and PV-OH } \\
3600-3400 \\
2950,1380,1440 \\
1740,1240 \\
1130,1030 \\
1100 \\
940,800\end{array}$ & $\begin{array}{l}-\mathrm{OH} \text { (hydrogen bonded in } \mathrm{PV}-\mathrm{OH}) \\
\mathrm{C}-\mathrm{H} \text { absorbance }\left(\mathrm{CH}_{3} \text { and } \mathrm{CH}_{2}\right) \\
\mathrm{C}=\mathrm{O} \text { of acetate (residual in } \mathrm{PV}-\mathrm{OH}) \\
\mathrm{C}-\mathrm{O}-\mathrm{C} \text { of ester }(\mathrm{PVA}) \\
2^{\circ}-\mathrm{OH} \text { of } \mathrm{PV}-\mathrm{OH} \\
\left.\mathrm{C}-\mathrm{C} \text { stretch (at } 850 \mathrm{~cm}^{-1} \text { in } \mathrm{PV}-\mathrm{OH}\right)\end{array}$ \\
\hline $\begin{array}{l}\text { Collagen/gelatin } \\
3400 \\
2950,1450,1400 \\
1650,1550,1240 \\
1090,1030\end{array}$ & $\begin{array}{l}-\mathrm{OH} \text { (hydrogen bonded), and } \mathrm{N}-\mathrm{H} \\
\mathrm{C}-\mathrm{H} \text { absorbance }\left(\mathrm{CH}_{3} \text { and } \mathrm{CH}_{2}\right) \\
\text { Amide } \mathrm{I} \text {, II, and } \mathrm{III} \text {, respectively } \\
2^{\circ} \text { and } 1^{\circ}-\mathrm{OH} \text {, respectively }\end{array}$ \\
\hline $\begin{array}{l}\text { Peptides } \\
1725,1220 \\
1650 \\
1480 \text { region } \\
1400\end{array}$ & $\begin{array}{l}\mathrm{C}=\mathrm{O} \text { of }-\mathrm{COOH} \text { (carboxylic acid) } \\
\text { Amide I } \\
\mathrm{C}-\mathrm{H} \text { absorbance } \\
\mathrm{C}=\mathrm{O} \text { of }-\mathrm{COO}^{-} \mathrm{NH}^{+} \text {(carboxylic acid salt) }\end{array}$ \\
\hline
\end{tabular}

*From Haslem, Willis \& Squirrel (1972); Bradbury et al. (1958)

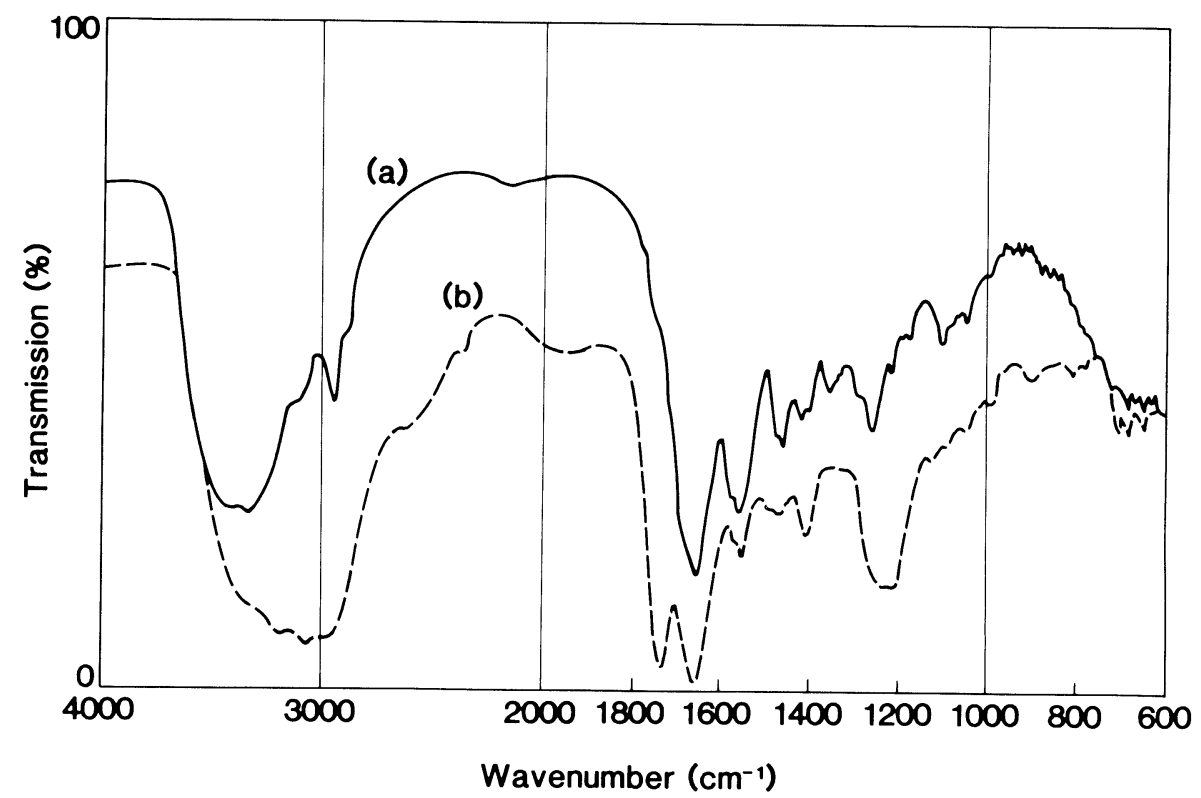

Fig. 2. Infra-red spectra of modern bovine collagen: (a) before partial hydrolysis by $0.1 \mathrm{M} \mathrm{HCl}\left(100^{\circ} \mathrm{C}, 16 \mathrm{~h}\right)$; (b) after partial hydrolysis by $0.1 \mathrm{M} \mathrm{HCl}\left(100^{\circ} \mathrm{C}, 16 \mathrm{~h}\right)$ 
TABLE 3. Summary chart of predominant functional groups (as detected by IR spectroscopy) present in fractions extracted from conserved bones

\begin{tabular}{|c|c|c|c|c|c|c|c|}
\hline \multirow{4}{*}{$\begin{array}{l}\text { Context/ } \\
\text { fraction }\end{array}$} & \multicolumn{7}{|c|}{ Functional Group } \\
\hline & \multicolumn{3}{|c|}{ Consolidant } & \multicolumn{4}{|c|}{ Protein } \\
\hline & \multirow{2}{*}{$\begin{array}{c}\text { Acetate } \\
\mathrm{C}=\mathrm{O}\end{array}$} & \multirow{2}{*}{$\begin{array}{l}2^{\circ}-\mathrm{OH} \\
(\mathrm{PV}-\mathrm{OH})\end{array}$} & \multirow{2}{*}{$\begin{array}{l}\text { Ester } \\
\text { C-O-C }\end{array}$} & \multicolumn{2}{|c|}{ Amide } & \multicolumn{2}{|c|}{ Peptide } \\
\hline & & & & I & II & $\mathrm{COOH}$ & $\mathrm{COO}^{-}$ \\
\hline$[\mathrm{F} 7] \mathrm{c}^{*}$ & $+* *$ & + & + & + & + & $-^{\dagger}$ & - \\
\hline$[\mathrm{F} 110] \mathrm{c}$ & + & + & + & + & + & - & - \\
\hline [F7]g & - & - & - & + & + & - & - \\
\hline [F110]g & $\mathrm{w}^{\ddagger}$ & + & + & + & + & - & - \\
\hline [17F232]g & - & - & - & + & w & + & - \\
\hline$[\mathrm{F} 251] \mathrm{g}$ & - & - & - & + & w & + & - \\
\hline$[\mathrm{F} 7] \mathrm{i}$ & - & - & - & + & w & - & + \\
\hline [F110]i & - & - & - & + & $\mathrm{w}$ & - & + \\
\hline$[17 \mathrm{~F} 232] \mathrm{i}$ & - & - & $\mathrm{w} ?$ & + & $\mathrm{w}$ & - & + \\
\hline$[\mathrm{F} 251] \mathrm{i}$ & - & - & $\mathrm{w} ?$ & + & $\mathrm{w}$ & - & + \\
\hline
\end{tabular}

${ }^{*} \mathrm{c}=$ crude collagen; $\mathrm{g}=$ crude gelatin; $\mathrm{i}=$ ion-exchanged gelatin

**+ Strong absorbance attributable to group present in spectra

$\dagger$ - No absorbance attributable to group is observed

${ }^{\ddagger} \mathrm{W}$ Weak absorbance, may be due to presence of specified group

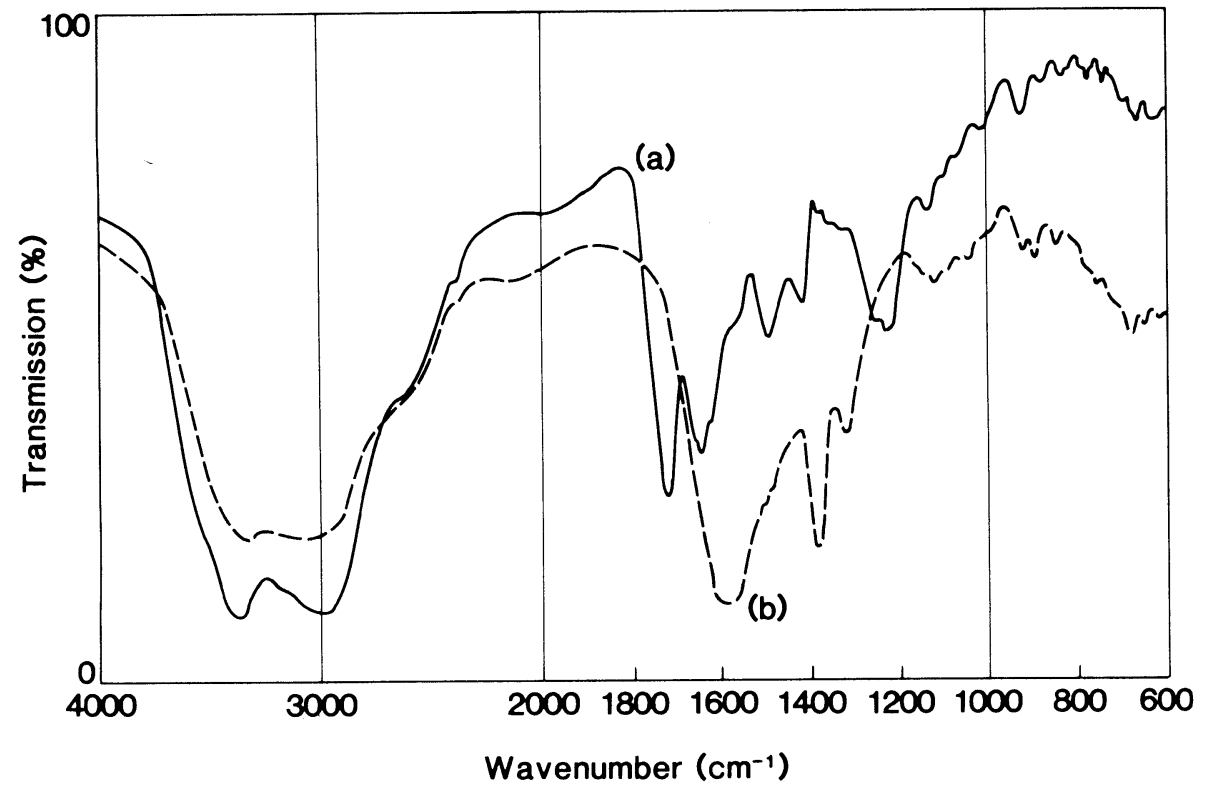

Fig. 3. Infra-red spectra showing peptized gelatin extracts from Burial 7 [17 $\mathrm{F} 232]$; (a) $\mathrm{H}^{+}$form, (b) $\mathrm{NH}_{4}{ }^{+}$form after ion exchange on BioRad AGMP-50 resin 
TABLE 4. AMS Dates on Human and Animal Bone From Cuello, Belize

\begin{tabular}{|c|c|c|c|c|c|}
\hline \multirow{2}{*}{$\begin{array}{l}\text { Context and } \\
\text { fraction }\end{array}$} & \multirow[b]{2}{*}{ OxA no. } & \multirow[b]{2}{*}{${ }^{14} \mathrm{C}$ date (BP) } & \multirow[b]{2}{*}{$\delta^{13} \mathrm{C}(\% 0)$} & \multicolumn{2}{|c|}{ Calibrated ranges* } \\
\hline & & & & 1 sigma & 2 sigma \\
\hline \multicolumn{6}{|l|}{ Human } \\
\hline$[\mathrm{F} 7] \mathrm{c}^{* *}$ & $\mathrm{p}^{\dagger} 1653$ & $2460 \pm 70$ & $-11.0^{\ddagger}$ & 760-410 в.C. & $780-400$ В.C. \\
\hline $10[\mathrm{~F} 7] \mathrm{g}$ & p 1654 & $2520 \pm 70$ & $-11.0^{\ddagger}$ & 800-530 В.С. & $805-410$ в.С. \\
\hline$[\mathrm{F} 7] \mathrm{i}$ & p 1655 & $2530 \pm 80$ & $-11.0^{\ddagger}$ & $810-410$ в.C. & $810-410$ B.C. \\
\hline$[\mathrm{F} 110] \mathrm{c}$ & p 1648 & $3750 \pm 70$ & $-11.0^{\ddagger}$ & $2300-2040$ в.С. & 2460-1980 в.C. \\
\hline [F110]g & p 1649 & $3000 \pm 60$ & $-11.0^{\ddagger}$ & $1380-1135$ в.С. & $1410-1060$ в.С. \\
\hline $62[$ F110]a & p 2103 & $2840 \pm 100$ & -10.4 & 1205-900 в.С. & 1305-815 в.C. \\
\hline [F110]r & p 2112 & $4540 \pm 100$ & -31.9 & 3375-3045 в.С. & 3600-2925 в.С. \\
\hline$[\mathrm{F} 110] \mathrm{a}$ & -2166 & $2830 \pm 70$ & -12.9 & $1120-905$ в.С. & $1255-835$ в.C. \\
\hline $123[\mathrm{~F} 251] \mathrm{a}$ & p 2016 & $2390 \pm 70$ & $-11.0^{\ddagger}$ & $760-395$ В.C. & $770-385$ в.C. \\
\hline$[17 \mathrm{~F} 232] \mathrm{a}$ & p 2017 & $2560 \pm 70$ & $-11.0^{\ddagger}$ & $810-540$ В.С. & $840-410$ В.C. \\
\hline \multicolumn{6}{|l|}{ Animal } \\
\hline [Q114]a & -1811 & $2700 \pm 90$ & -20.1 & $985-800$ в.С. & $1125-550$ в.С. \\
\hline [Q146]a & -1810 & $2470 \pm 80$ & -15.9 & $765-415$ в.С. & $785-405$ в.С. \\
\hline [Q44]a & -2019 & $1650 \pm 70$ & -15.6 & A.D. $255-525$ & A.D. $235-555$ \\
\hline [Q23]a & -2018 & $1230 \pm 80$ & -13.3 & A.D. $690-880$ & A.D. $660-965$ \\
\hline [Q109]a & -1809 & $910 \pm 120$ & $-20.0^{\ddagger}$ & A.D. $1015-1235$ & A.D. $890-1285$ \\
\hline$[\mathrm{Q} 74] \mathrm{a}$ & -1808 & $880 \pm 110$ & -19.9 & A.D. $1035-1235$ & A.D. $900-1290$ \\
\hline \multicolumn{6}{|c|}{$\begin{array}{l}\text { *Dendrochronological calibration based on high-precision curves of Stuiver \& Pearson (1986); Pearson \& Stuiver (1986); } \\
\text { Pearson et al. (1986); and the calibration computer program of van der Plicht \& Mook (1989). } \\
* \mathrm{c}=\text { crude collagen; } \mathrm{g}=\text { crude gelatin; } \mathrm{i}=\text { ion-exchanged gelatin; a = amino acids from ion-exchanged gelatin; } \mathrm{r}=\text { residue } \\
\text { from gelatinization stage } \\
{ }^{\dagger} \mathrm{p}=\text { bone with PVA/PV-OH preservative; - = bone without PVA/PV-OH preservative } \\
{ }^{*} \text { assumed (not measured) } \delta^{13} \mathrm{C} \text { values. The humans are assumed to have been eating maize, the }-11 \% \text { value being an } \\
\text { approximate estimate based on the two measured bones which do indicate maize was an important component of the diet. } \\
\text { The }-20 \% \circ \text { value is based on the } \delta^{13} \mathrm{C} \text { measured for Q109, the other Postclassic animal bone, but since the species identity } \\
\text { of the two bones is unknown, there is a margin of error. }\end{array}$} \\
\hline
\end{tabular}

reduction in the amide II absorbance, which is due partly to the presence of $\mathrm{C}-\mathrm{N}$ bonds, supports the peptization theory. As these changes are not normally seen with better preserved samples, it would appear that the effect is due largely to the action of the tropical environment. Absorption in the region of acetate, alcohol and ester groups is weak for these samples, and similar in magnitude to that observed in the spectra of pure samples.

From the IR spectra, it appears that gelatinization and filtration alone may not remove adequately consolidants from bone extracts, but that ion exchange of the gelatin fraction does. However, the detection limits for contaminants using IR spectroscopy are such that observing contamination at the level of a few percent is not always possible, especially when diagenetic changes to the bone protein complicate the spectra. For this reason, hydrolysis of the proteins/peptides to free amino acids is usually carried out, and these are purified by ion-exchange chromatography.

\section{SIGNIFICANCE OF ${ }^{14} \mathrm{C}$ MEASUREMENTS}

The dates obtained on the "control" samples, Q146 and Q114, are as expected, on stratigraphic and ceramic-typological grounds, and can be used as criteria by which the dates obtained on the conserved samples can be judged. From these dates, it appears that removal of environmental 
contaminants has been achieved by the pretreatment. Acceptable ${ }^{14} \mathrm{C}$ ages have also been obtained on the purified amino-acid fractions of the consolidated samples. When the dates obtained on the intermediate fractions from Burials 10 and 62 are studied, we can see that, where contamination of the sample by consolidant was high ( $c f$. Burial 62, Fig. 4), a steady improvement in dating is obtained as the degree of purification increases, i.e., the dates become younger, although the difference in age between the two gelatin fractions is not significant.

With Burial 10, the uniformity of the ${ }^{14} \mathrm{C}$ ages obtained on the three fractions points to less severe contamination, although consolidant was visible on the IR spectrum of the crude collagen fraction. In this case, gelatinization and filtration was sufficient to reduce the levels of PVA and PV-OH to below the IR detection limits.

Polymers such as PVA and PV-OH are normally manufactured from petrochemical precursors, and should contain no ${ }^{14} \mathrm{C}$ atoms. It would have been better to date the preservatives directly, but they were unavailable at the time of this study. When the residue remaining after the extraction of gelatin from Burial 62 was isolated and dated, a ${ }^{14} \mathrm{C}$ "age" of $4540 \pm 100$ B.P. was obtained, indicating that the residue probably contained "young" carbon from humic materials and insoluble collagen, as well as consolidant. The IR spectrum of the residue (Fig. 5B) showed that the strongest absorbance was in the $\mathrm{C}-\mathrm{O}-\mathrm{C}$ (from ester and ether groups) and $\mathrm{O}-\mathrm{H}$ regions. Although this could be attributed to consolidant, the lack of definition in the spectrum indicates that environmental contaminants were also present.

No intermediate fractions were dated from Burials 123 and 7, but IR spectra on ion-exchanged gelatin showed that PVA and PV-OH were absent. The ${ }^{14} \mathrm{C}$ dates should, therefore, reflect the true age of the samples.

Non-Burial Post-Preclassic Bone. These samples had not been consolidated during excavation, nor had they been conserved subsequently. They were expected to pose problems caused by low levels of collagen and relatively high levels of soil-derived contaminants. In practice, 3 out of the 4 samples were relatively high in collagen, but Sample Q109, while having virtually no collagenous protein that could be extracted as gelatin, had an apparent "collagen" yield of $165 \mathrm{mg} \mathrm{g}^{-1}$. With the other samples, between $70 \%$ and $25 \%$ of the crude collagen fraction was extractable as gelatin.

In such cases, the "collagen" fraction is a mixture of true collagen, diagenetically altered collagen (often not extractable as gelatin) and soil-derived material such as humic acids, rootlets and clay. Hydrolysis of this will release amino acids and sugars from all available sources, and these are likely to be "young," especially in tropical environments where turnover of unprotected organic matter is rapid. The amino-acid part of any aminosugar formed during hydrolysis need not derive from contamination; it is sufficient that the sugar part does, however. Purification of the hydrolyzate with decolorizing resins and ion exchange will remove non-amino contaminants only, leaving some "young" material in the final dating sample. This probably explains why the early AMS dates on amino acids from "collagen" were too young, even when the consolidant contaminants were "old."

The extraction of gelatin eliminates much of the environmental contaminants, although fulvic materials and, possibly, oligo- and polysaccharides associated with humic acids, can be co-extracted with the gelatin. These are removed by ion exchange of the proteins/peptides. The most important result, from the view of pretreatment in this section, is the date obtained on Q109, because this sample had only about $0.25 \%$ of its original collagen remaining as extractable gelatin. Previously, our laboratory methods were unsuitable for bones where less than about $5 \%$ of the original collagen remained. However, the accuracy of the date is supported by the agreement with that measured on 


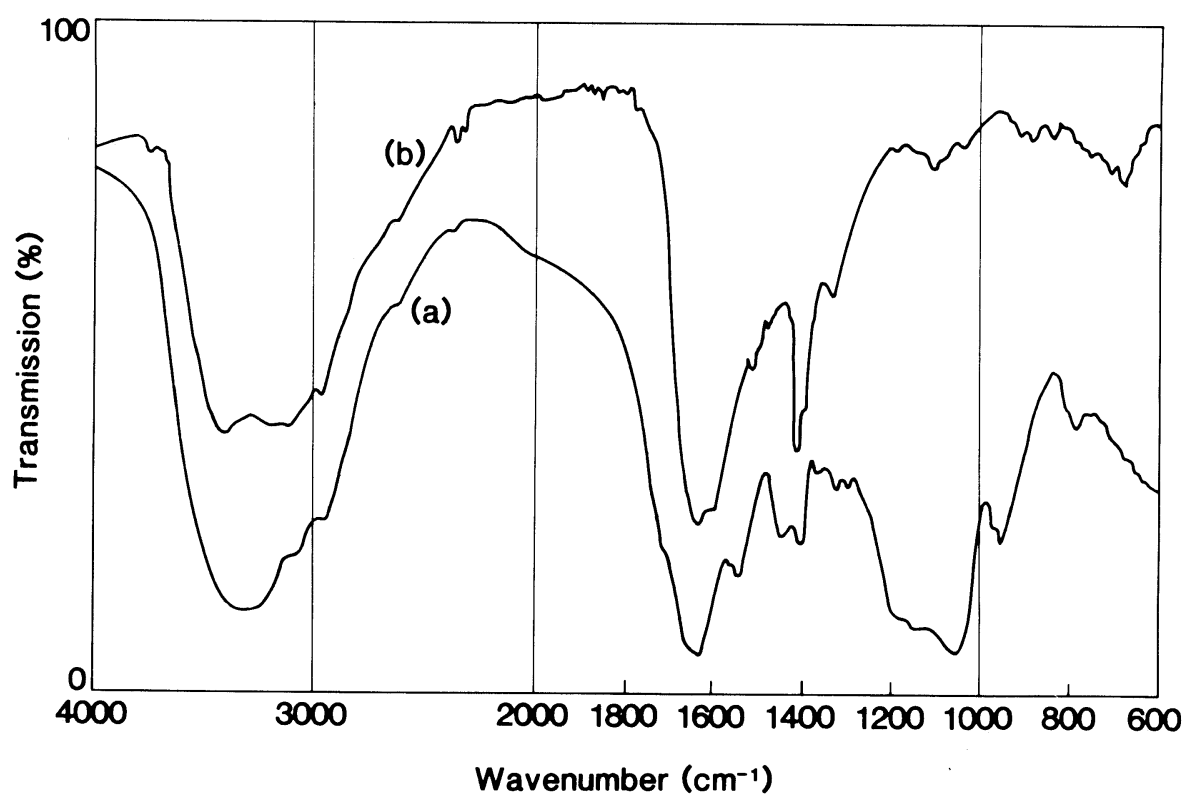

Fig. 4. Infra-red spectra of (a) crude gelatin, and (b) ion-exchanged gelatin fractions extracted from Burial 62 [F110]

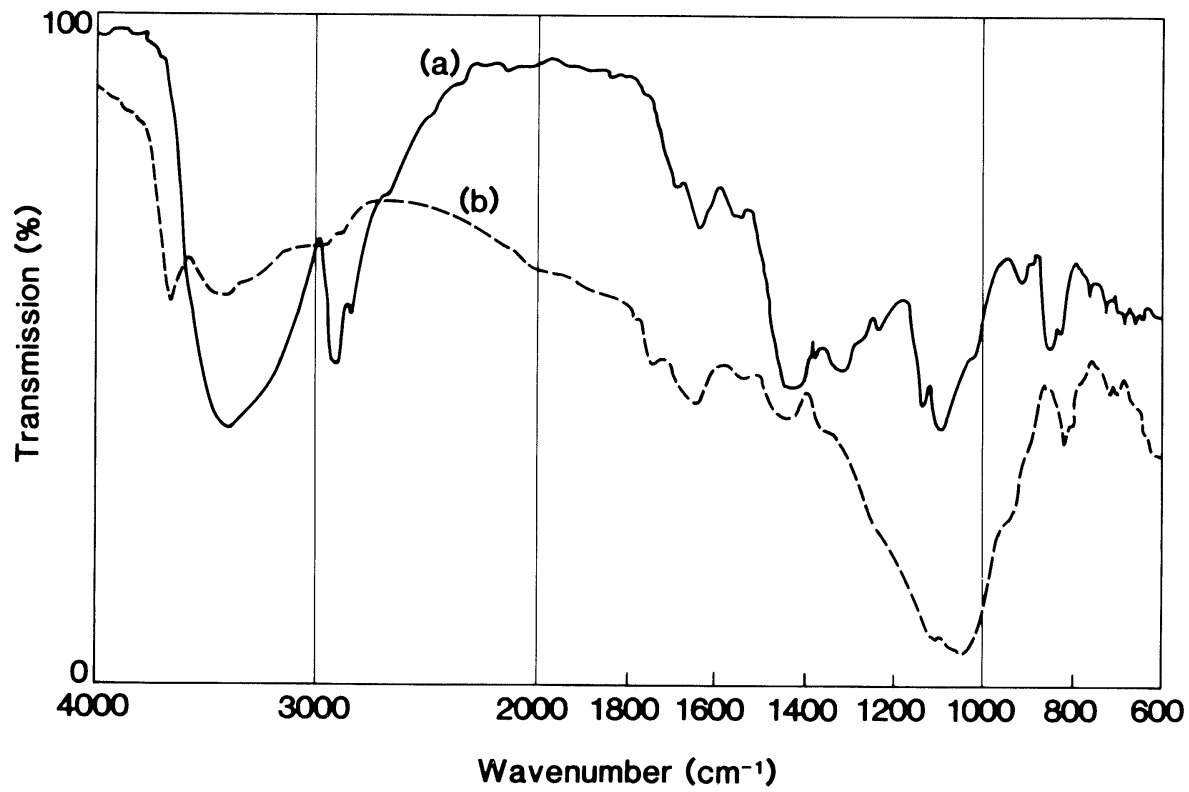

Fig. 5. Infra-red spectra showing (a) PV-OH, 14,000 mw (BDH Ltd.), and (b) residue remaining after extraction of crude gelatin from the "collagen" fraction of Burial 62 [F110] 
the associated sample, Q74, and shows that our present pretreatment procedures can deal with very low levels of surviving collagen.

It is important to note that the methods and approaches adopted here correspond more or less to our 'routine' pretreatment methods for bone, which this project has, to a small extent, helped to validate. The circumstances in which we believe them to be valid very roughly apply to Holocene bone containing small but significant quantities of collagenous protein (at least $1 \%$, i.e., $2 \mathrm{mg} \mathrm{g}^{-1}$, surviving extractable collagen), and subject to massive non-proteinaceous contamination. The general problem of radiocarbon dating bone, particularly in more extreme circumstances (i.e., both older, and very much more reduced in collagen content, often to the point where only noncollagenous material remains) is the subject of much active research. See, eg, Stafford et al. (1991), van Klinken \& Mook (1990), Ajie et al. (1990), Hedges \& Law (1989) and references therein. However, we believe that the work reported here demonstrates the value of selective pretreatment aimed at isolating a truly representative protein/peptide fraction from degraded bone before any quantitative measurements $\left(\right.$ e.g. $,{ }^{14} \mathrm{C}, \delta{ }^{13} \mathrm{C}$, amino-acid content) are attempted.

\section{CONCLUSIONS}

The ability of the AMS technique to handle milligram-sized samples allows separate fractions to be dated, so that the effect of the purification process can be monitored. Comparison of dates obtained on intermediate fractions with their IR spectra illustrates how IR spectroscopy can be used to assess the progress of the purification procedures. Using this technique, contamination in the dating sample can be detected, even when the ${ }^{14} \mathrm{C}$ age of the net contamination does not differ greatly from that of the sample. This makes the evaluation of purification procedures less reliant on the actual ${ }^{14} \mathrm{C}$ measurement, and applicable to a wider range of samples.

Although supported by two Preclassic non-human bone dates, Q114 and Q146, the four ${ }^{14} \mathrm{C}$ dated burials from Cuello $(7,10,62,123)$, should be considered with some caution. However, we believe that we have come some way to resolving the controversy over the "long" and "short" chronologies for Cuello. We have obtained a set of direct dates that suggest an occupation beginning in the late second millennium cal. B.C., and that support the new ceramic chronology advanced by Andrews \& Hammond (1990). Although this time span is over a millennium shorter than that initially proposed for Cuello, it is several centuries longer than the disturbingly recent dates for the Swasey phase indicated by the "short" chronology. If our direct dating of human burials is supported by further research, the chronology would place the Lopez Mamom phase at $c a .650-400$ cal. B.C., the preceding Bladen phase at $c a .900-650$ cal. B.C., and the Swasey phase at $c a .1200-900 \mathrm{cal}$. B.C. (Fig. 1). The dates for Mamom sphere ceramic complexes elsewhere, and for the Xe complex, which is the equivalent of Bladen further southwest in the Maya lowlands, would be in close agreement with the revised Cuello chronology.

The stratigraphically late animal bone samples, especially Q74 and Q109, indicate that architectural additions to the temple-pyramid Structure 35 were still being made, and the residential group just to the north was still occupied in the Postclassic period. The 12th century A.D. date suggested accords with other archaeological evidence from Cuello, which until now had been interpreted as only a pilgrimage visitation of the site from a nearby community (Hammond, Housley \& Law 1991).

Overall, the application of AMS dating to microscopic samples of organic material from badly denatured human and animal bone has proved remarkably successful in resolving vexing matters of ancient Maya chronology. 


\section{REFERENCES}

Ajie, H. O., Kaplan, I. R., Slota, P. J., Jr. and Taylor, R. E. 1990 AMS radiocarbon dating of bone osteocalcin. In Yiou, F. and Raisbeck, G. M., eds., Proceedings of the 5th International AMS Conference. Nuclear Instruments and Methods B52: 433-437.

Andrews, V, E. W. 1991 The early ceramic history of the Lowland Maya. In Harrison, P. D. and Clancy, F., eds., Vision and Revision in Maya Studies. Albuquerque, University of New Mexico Press: 1-19.

Andrews, V, E. W. and Hammond, N. 1990 Redefinition of the Swasey phase at Cuello, Belize. American Antiquity 55(3): 570-584.

Bradbury, E. M., Burge, R. E., Randall, J. T. and Wilkinson, G. R. 1958 The polypeptide chain configurations of native and denatured collagen fibres. Discussions of the Faraday Society 25: 173-185.

Coe, M. D. 1980 The Maya, 3rd edition. London, Thames and Hudson.

Donaghey, S., Pring, D., Wilk, R., Saul, F. P., Feldman, L. H. and Hammond, N. 1976 Excavations at Cuello, 1976. In Hammond, N., ed., Archaeology in Northern Belize. Corozal Project 1976 Interim Report. Centre for Latin American Studies, Cambridge University: 6-59.

Gillespie, R., Hedges, R. E. M. and Humm, M. J. 1986 Routine AMS dating of bone and shell proteins. In Stuiver, M. and Kra, R. S., eds., Proceedings of the 12th International ${ }^{14} \mathrm{C}$ Conference. Radiocarbon 28(2A): 451-456.

Gowlett, J. A. J., Hall, E. T., Hedges, R. E. M. and Perry, C. 1986 Radiocarbon dates from the Oxford AMS system: Datelist 3. Archaeometry 28(1): 116125

Hammond, N. 1980 Early Maya ceremonial at Cuello, Belize. Antiquity 54: 176-190.

1984 Two roads diverged: A brief comment on "Lowland Maya archaeology at the crossroads." American Antiquity 49(4): 821-826.

Hammond, N., Donaghey, S., Berger, R., de Atley, S., Switsur, V. R. and Ward, A. P. 1977 Maya Formative phase radiocarbon dates from Belize. Nature 267: 608-610.

Hammond, N., Housley, R. A. and Law, I. A. 1991 The Postclassic at Cuello, Belize. Ancient Mesoamerica 2(1): 71-74.

Hammond, N., Pring, D., Berger, R., Switsur, V. R. and Ward, A. P. 1976 Radiocarbon chronology for early Maya occupation at Cuello, Belize. Nature 260: 579-581.

Hammond, N., Pring, D., Wilk, R., Donaghey, S., Saul, F. P., Wing, E. S., Miller, A. V. and Feldman, L. H. 1979 The earliest Lowland Maya? Definition of the Swasey phase. American Antiquity 44 (1): 92-110.

Haslam, J., Willis, H. A. and Squirrel, D. C. M. 1972 Identification and Analysis of Plastics, 2nd edition. London.

Hedges, R. E. M. and Law, I. A. 1989 The radiocarbon dating of bone. Applied Geochemistry 4: 249-253.

Hedges, R. E. M., Law, I. A., Bronk, C. R. and Hou- sley, R. A. 1989 The Oxford accelerator mass spectrometry facility: Technical developments in routine dating. Archaeometry 31(2): 99-114.

Horie, C. V. 1987 Materials for Conservation. London, Butterworth: 281 p.

Klinken, van, G. J. and Mook, W. G. 1990 Preparative high-performance liquid chromatographic separation of individual amino acids derived from fossil bone collagen. Radiocarbon 32(2): 155-164.

Law, I. A. and Hedges, R. E. M. 1989 A semi-automated bone pretreatment system and the pretreatment of older and contaminated samples. In Long, A. and Kra, R. S., eds., Proceedings of the 13th International ${ }^{14} \mathrm{C}$ Conference. Radiocarbon 31(3): 247-253.

Linick, T. W. 1984 La Jolla natural radiocarbon measurements X. Radiocarbon 26(1): 75-110.

Lowe, G. W. 1978 Eastern Mesoamerica. In Taylor, R. E. and Meighan, C. W., eds., Chronologies in New World Archaeology. New York, Academic Press: 331-393.

Marcus, J. 1983 Lowland Maya archaeology at the crossroads. American Antiquity 48: 454-488.

1984 Reply to Hammond and Andrews. American Antiquity 49(4): 829-833.

Pearson, G. W., Pilcher, J. R., Baillie, M. G. L., Corbett, D. M. and Qua, F. 1986 High-precision ${ }^{14} \mathrm{C}$ measurement of Irish oaks to show the natural ${ }^{14} \mathrm{C}$ variations from A.D. 1840 to 5210 B.C. In Stuiver, M and Kra, R. S., eds., Proceedings of the 12th International ${ }^{14} \mathrm{C}$ Conference. Radiocarbon 28(2B): 911 934.

Pearson, G. W. and Stuiver, M. 1986 High-precision calibration of the radiocarbon time scale, 500-2500 B.C. In Stuiver, M. and Kra, R. S., eds., Proceedings of the 12 th International ${ }^{14} \mathrm{C}$ Conference. Radiocar bon 28(2B): 839-862.

Plicht, van der, J. and Mook, W. G. 1989 Calibration of radiocarbon ages by computer. In Long, A. and Kra, R. S., Proceedings of the 13 th International ${ }^{14} \mathrm{C}$ Conference. Radiocarbon 31(3): 805-816.

Pring, D. and Hammond, N. 1982 The stratigraphic priority of Swasey ceramics at Cuello, Belize. Ceramica de Cultura Maya et al. 12: 43-48.

Smith, R. E. 1955 Ceramic sequence at Uaxactum, Guatemala. Middle American Research Institute Publication 20 (2 vols.), Tulane University.

Stafford, T. W., Jr., Hare, P. E., Currie, L., Jull, A. J. T. and Donahue, D. J. 1991 Accelerator radiocarbon dating at the molecular level. Journal of Archaeological Science 18(1): 35-72.

Stuiver, M. and Pearson, G. W. 1986 High-precision calibration of the radiocarbon time scale, A.D. 1950 500 B.C. In Stuiver, M. and Kra, R. S., eds., Proceedings of the 12 th International ${ }^{14} \mathrm{C}$ Conference. Radiocarbon 28(2B): 805-838.

Timasheff, S. N. and Susi, H. 1966 Infrared investigations of the secondary structure of $\beta$-Lactoglobulins. Journal of Biological Chemistry 241: 249-251. 